\title{
ESTRATÉGIAS DE COMBATE PARA BIOFILMES, UM DESAFIO ENDODÔNTICO
}

\author{
FIGHTING STRATEGIES TO BIOFILMS, A ENDODONTIC CHALLENGE
}

\begin{abstract}
de Almeida J., Hoogenkamp M., Felippe WT, Crielaard W., Van der Waal SV. Effectiveness of EDTA and Modified Salt Solution to Detach and Kill Cells from Enterococcus faecalis Biofilm. J Endod., 2016, Feb; 42(2): 320-3. doi: 10.1016/j.joen.2015.11.017.
\end{abstract}

LeOPOLdo Cosme-SiLVA Mestrando em Ciências Odontológicas - UNIFAL-MG

RAYANA DUARTE KHOURY Mestranda em Odontologia Restauradora - ICT-UNESP

O biofilme apical certamente representa um grande desafio na endodontia. A eliminação de microrganismos do sistema de canais radiculares infectados com lesão perirradicular associada tem sido uma constante preocupação clínica. A periodontite apical é uma resposta inflamatória à presença de biofilme, que tem sido combatida por meio do uso de irrigantes, medicações intracanais, com a ação mecânica dos instrumentos endodônticos. No entanto, muitas das substâncias utilizadas como irrigantes apenas reduzem a carga de bactérias presentes no canal radicular, mas dificilmente as eliminam por completo. Essa dificuldade na remoção total das bactérias é atribuída à redução da suscetibilidade das mesmas quando estas se encontram na forma de biofilme, que consiste em comunidades organizadas, aderidas na superfície e envolvidas por uma substância polimérica extracelular (EPS). Além disso, o hipoclorito de sódio e a clorexidina, que representam as substâncias irrigantes mais difundidas na endodontia, são excelentes desinfetantes superficiais, no entanto, fracassam em penetrar inteiramente nas placas de biofilme.

Entre os diversos componentes que compõem o EPS, o $\mathrm{Ca}_{2+}$, que também está presente, desempenha um papel fundamental na manutenção da estabilidade, arquitetura, viscosidade e força do biofilme. O rompimento dessa matriz de biofilme endodôntico certamente contribui para a sua remoção do canal radicular. No campo da endodontia, o EDTA é largamente utilizado com a função de remover a porção inorgânica contida na smear layer produzida em consequência da instrumentação. Em função dessa propriedade de dispersão, alguns autores também apontam o seu uso para "soltar" ou limpar o biofilme. Apesar de sua ação antimicrobiana ser limitada, poucos são os trabalhos que avaliam e quantificam o efeito de remoção e limpeza do biofilme fazendo uso do EDTA.

Outro irrigante vem sendo difundido e conhecido como Solução Salina Modificada. É uma solução hipertônica e tem se mostrado bastante eficaz na inativação do biofilme. Apesar da sua eficácia ter sido testada em modelos de biofilmes aderidos em substratos, ainda permanece uma dúvida: seria a redução microbiana causada pela morte das bactérias ou pelo descolamento das células do biofilme no substrato, ou por ambos os mecanismos?

Sendo assim, o estudo em questão procurou avaliar a efetividade do EDTA e da Solução Salina Modificada no descolamento da bactéria em biofilmes formados por Enterococcus faecalis e verificou que o EDTA destacou uma porção maior de células do 
biofilme. De acordo com a literatura, o seu bom desempenho pode ser atribuído ao sequestro de íons $\mathrm{Ca}_{2+}$ pelo EDTA, causando um enfraquecimento na estrutura da matriz polimérica e por consequência uma diminuição da quantidade de biofilme, bem como a sua adesão, viscosidade e formação.

A solução salina modificada que é principalmente conhecida por sua atividade antimicrobiana também foi capaz de destacar as células de biofilme, provando ser um desinfetante. Seu efeito de rompimento pode ser explicado por meio da reação de permuta entre íons $\mathrm{Na}^{+}$ou $\mathrm{K}^{+}$presentes na solução salina que se difundem e quebram as pontes de $\mathrm{Ca}^{2+}$ encontradas na matriz do biofilme. Por conseguinte, sua estrutura é enfraquecida, facilitando, portanto, a sua remoção.

Além do descolamento do biofilme, o estudo também reavaliou a propriedade antimicrobiana entre as substâncias em questão. O EDTA teve um menor efeito antimicrobiano e um desempenho insatisfatório quando comparado à Solução Salina Modificada.
$\mathrm{Na}$ endodontia, o EDTA é usado sinergicamente com o $\mathrm{NaOCl}$ (hiploclorito de sódio), e sua ação quelante contribui e facilita a atividade antimicrobiana do hipoclorito de sódio. Todavia, devemos atentar para o fato de que o EDTA, quando misturado com o hipoclorito de sódio, tende a reduzir o componente de cloro ativo presente no $\mathrm{NaOCl}$. Além disso, o EDTA provoca uma erosão de dentina intertubular. Portanto, fazse necessária a busca de novas substâncias, por exemplo, a Solução Salina Modificada, que no estudo presente apresentou bons resultados, reunindo importantes prpriedades em um único produto, sendo uma alternativa para o uso do EDTA e $\mathrm{NaOCl}$. Estudos futuros devem investigar a atuação da Solução Salina Modificada quanto à remoção de smear layer.

Estudos como este nos fazem pensar além, para que se possa buscar novas direções em pesquisas futuras, abordando a questão dos biofilmes que se mostram como um grande obstáculo no cotidiano clínico. 